\title{
The Interaction of Two Cultural Models in Lithuanian Pedagogical Thought During the 16th-17th Centuries
}

\section{Ingè LUKŠAITE}

The culture of mankind as a whole, and of some of its constituent parts, such as ethne, in particular, can be defined through the organization and relationship of this ethnic unit, its complex of values and their changing hierarchy, its emotional attitude and world outlook, as well as the means of their expression, its past experience which formed its cultural integrity.

Franz Boas (1858-1942), one of the founders of historical anthropology, suggested that cultural researchers, above all, cultural historians, as soon as they delineate the history of individual culture, should understand the environmental influences and psychological conditions that culture reflects. In this way, they will make a step forward and be able to realize what factors affect the development of cultures. Thus by comparing various evolutionary histories they can determine general tendencies. This method is much more reliable than the comparative one in all its shapes, as the basis of our deduction is real history, not the hypothesis on the subject of evolution ${ }^{1}$.

Guided by this precept, Lithuanian cultural historians have undertaken a study of the history of their ethnic culture, as a cultural whole, and of individual culture, affected by a number of factors, including other cultures; they have begun to investigate that culture's internal relations as well as the patterns of its relationship with the cultures of other ethnic entities.

The general models of communicating knowledge, thought, philosophy of life, world outlook manifest themselves in concrete spheres of culture.

Throughout the long centuries of its cultural evolution Lithuania has witnessed two dominant models of this evolution.

At the beginning of the Christian era, society had inherited a model dominated by social organisation based on the agrarian way of life, and resulting in the 9th-13th-century state structure, system of values, outlook. This cultural type was oral and, relatively, of little specialisation. Its primum movens was the agrarian community and 
the closely associated military stratum. In the course of several millennia this cultural model developed gradually and remained ethnically uniform - Baltic. It was united by the closely related languages of the same branch of the Indo-European family. It had preserved a wealth of world-perception, world-acquisition, old symbols and archetypes. This cultural type was more durable in Lithuania than in neighbouring lands, and in the 9th-13th centuries it developed far enough to evolve a socially stratified society. Its relations bore witness to the existence of a nation, the maturity of social organisation reaching the point when a state is created. A certain specialization was taking place in this Baltic culture - the agrarian community was differentiating into entrepreneurs, craftsmen, the military, political leaders headed by a sovereign. In the 13 th-14th centuries Lithuanian society was mature enough to adopt another type of culture existing in the neighbour states.

The second cultural type had a multimillennial history in the territory of the Mediterranean civilizations and in the area influenced by the former Roman Empire, inheriting many traditions from the culture of Antiquity. After the fall of the Roman Empire, those territories saw the formation of a number of nations. They lived creating their individual cultures, yet they all shared many common features. Part of the cultural spheres was based on script and the script-using institutions, on a well-developed state and ecclesiastic organisation, a more profound and greater specialisation in the sphere of production, a wider differentiation of the society. They had a powerful stratum of urban dwellers. This cultural model had long been predominant in the major realms of Western and Central Europe, alongside the agrarian one. In the cultural model where script was used so widely, there were favourable conditions for a more rapid dissemination of innovations, new technologies. The culture itself was far more individualized; its distinctive characteristic was the role of supranational language and the written forms of it. It possessed a great deal of elements from panEuropean culture. This was especially typical of the larger nations: those of the French, Italian, Spanish, English and Germans who had created their own states or lived in huge commonwealths (e.g. the Holy Roman Empire). The common denominators of the cultural domains of the major European states, based on the written word, can be viewed as the fundamental framework of a pan-European cultural model.

The Lithuanian nation, which created its own state in the 13 th century, had much closer contacts with the script-based cultural model as a result of the impact of intense military expansion into the region by western Europeans. The 13 th century was the beginning of a long period of the struggle, co-existence, adjustment and interaction between these two cultural models. They had lived side by side through long centuries. From the establishment of the state to its fall in the late 18th century the Baltic cultural model, the ways of com- 
municating its experience, the values, philosophy of life, language, its meanings and modes of expression were the form of cultural evolution for the majority of Lithuanians, for $90 \%$ of the Lithuanian nation: the peasantry, townspeople, part of the nobility, plenty of its phenomena remained vivid in the life of the "upper strata". The Baltic structure was developing and was influenced by the adjacent culture based on script and institutions. On the other hand, the cultural model founded on broad specialisation, formed professions using script, organisations functioning via the written word, to create official state institutions in Lithuania, and through these, this model began to spread in the "upper" strata. After the Conversion to Christianity, this model found a new propagator - the Church. The latter model, imported yet adoptive, also evolved in Lithuania under the influence of the development of the entire public life and the mode of production. Both these models of cultural evolution were interactive.

Through long millennia Baltic culture, dominated by its agrarian trend, was ethnically stable, while that based on script possessed a multitude of pan-European and great-power cultural elements, and during certain periods the latter were used by the more sizeable neighbouring nations as a means of cultural and political expansion into Lithuania. However, even the script-based culture, while preserving some properties of pan-European culture, in most other countries was implanted into the system of inherited ethnical culture. Therefore, Lithuanian cultural history in historic times can be viewed as a field of struggle, co-existence and interaction between two cultural models.

These processes were most notable in the development of education as one of the cultural domains. The history of Lithuanian education reveals a number of different ways to communicate public experience and to educate a human being. The adjustment of these two cultural models and the corresponding modes of education, which interact on each other has been taking place in Lithuania in the course of the 14th-20th centuries.

Education, i.e. the handing down of public experience to the younger generation, the expansion of adults' accumulated knowledge and anything that composes a man's upbringing, is as old as society itself. During individual stages of society's evolution the ways of communicating this experience have been different.

Both before the establishment of their state and for several centuries following its establishment in the 13th century the Lithuanians prepared the younger generation for life and the needs of their society according to their long-standing traditional method: experience would be communicated by the older generation by action or word, not in special schools, but in the family, in the homeplace, teaching skills to the children of craftsmen in artisans' workshops, in the castles or developing towns. Every healthy adolescent male was forced by the political situation of the 9 th- 15 th centuries to acquire 
some military skills, necessary for the defence of his homeland. The Lithuanian war with the Teutonic Order in Prussia and Livonia that lasted almost two centuries compelled every man to join the defence of the Lithuanian lands. During the time of Kestutis between 1341 and 1382 the Lithuanians had to repel 96 campaigns led by the Teutonic Order, while they themselves staged nearly 42 offensives. Some of the soldiers received special training and formed a standing army. The descendants of the ruler and the regional dukes were trained in a special way for the ruler's office. They were taught to lead an army, and would accumulate knowledge at the ruler's court, in castles. They had a stock of information on the other countries' style of administration and military art. Therefore, for hundreds of years the Lithuanian younger generation was trained for life by the deeds and example of the adults, common labour, the entire communal life of the family, villagers and castle-dwellers, oral art (folk-lore) and customs, rituals and common law. All those things taught labour, conduct, morals, created the ideal of a personality, developed the sense of beauty, formed attitudes towards values and their hierarchy. However, even as the state was established this whole method of education, based on practical experience, observation, action, was not committed to paper and so got little reflection in the written documents of that time. Attempts can be made to reconstruct and understand it from the relatively unexplored ways of Lithuanian activity and its results, from folk-lore that was recorded after many centuries and thus became fixed in an altered form.

During the first decades of the Lithuanian state, especially after baptism in 1387, efforts began in Lithuania to seek ways of learning to write and implementing the "European" system of education. The first instances of using script appeared in the 13th century when it came to be applied for the diplomatic needs of the newly established state. The first literate people arrived in Lithuania from the neighbour countries that had schools which gave instructions in writing to the young for monasteries, state administration and the high offices of the Church. In the beginning educated people would be summoned for the demands of the Lithuanian state from Catholic (Dominican and Franciscan friaries, for example, for the writing of Gediminas' letters) and somewhat later also from Orthodox monasteries.

In the 14th-15th centuries the major state institution that needed literate people was the scriptorium, after the introduction of Christianity - the Church. Scriptoria gave instruction in written languages, writing and the rules of document preparation. Tuition at them was organized according to the pedagogical methods, based on practical experience: example, the established habits; an important factor was the personal qualities of the chief scribe and his relationship with the pupil - no doubt, all this depended on certain attitudes towards the ways and methods of experience communication, yet in 
the 13th-14th centuries they are neither extant nor recorded in the Lithuanian documents.

After Christianity had been introduced in Lithuania in the 14th century, another form of education undertaken by the Church made its appearance. It taught the principles of faith and influenced society by rituals, especially by sermons. By using all this, the Church was motivating certain behavioural rules. The majority of them, for instance, such as "do not murder", "do not steal" - had been obvious to Lithuanian society long before baptism. These had been formed as the beginning of human co-existence, as had a stable family and the principle ownership. After baptism these rules began to acquire another motivation - the doctrine was, that one ought to behave so, because such was the will of the Christian God. During the centuries since 1387 the Church's activity had involved ever broader sections of the society, directed the peoples' behaviour and personal philosophy of life, changed the old culture and sometimes even adapted to the ancient Baltic culture. Church ceremonies and sermons were addressed to everybody, i.e. people of different age, yet often they would be the same for various estates of the realm and during the epoch of feudalism they fostered class regulations; for example, landlords were taught benevolence to their subjects but also the legitimacy of authority over another person, and a serf peasant - to be obedient and compliant with his situation. The church instruction was a permanently acting institution of the formation and correction of regulations, thus one more way of society's education.

Conditions for the development of a new type of pedagogical thought in Lithuania were created by the fact that public life in Lithuania was becoming more and more open to the Western and Central European Latin school, which possessed long-lasting experience and evolution in Catholic countries. This school system, based on Latin language instruction, consisted of several types of schools whose establishment was begun in Lithuania late in the 14th century. Young men wishing to become monks were taught at boarding-schools by the monasteries; the children of townspeople and the gentry received primary education at parish schools which existed in Lithuania from 1409 and were run by churches; part of the gentry and magnates gave primary and secondary education to their children at the home schools; candidates for theological studies completed their secondary education at the Cathedral Schools of Vilnius (1397) and Varniai (1469). It was not until the mid-16th century that secular public grammar schools were established in Lithuania. Those willing to study at the universities of Central and Western Europe had to find a way to prepare for the standards of the university level, and this presented some worries to magnates, rich burghers and nobles: alike one had to find proper teachers, maintain them at home, later to accommodate a youth in a foreign country and to pay abroad for the individual tutors - university professors and teachers, to find and finance special study 
advisers - tutors. Thus higher education was not accessible to many. In the course of the 15 th century the number of Lithuanian students at the University of Cracow alone was 200. Lithuanian youths studied in the universities of Germany and distant Italy. The demand for educated people in the Grand Duchy of Lithuania, which during the 15th century was rapidly adjusting to the civilisation and the forms of government in Western and Central Europe, was high. It needed chancery clerks with a command of 4 languages, priests, studying theology at diocesan chapters, cathedral schools, barristers completing law studies, and officials for high administrative posts. Commercial and guild activities (thriving in Lithuania from the late 15 th century) required such education as was offered by the earlier developed educational system in Europe, that from the early 16th century was subject to vigorous reforms.

The curriculum of the Western and Central European educational system was virtually uniform all across the Continent. This uniformity was enhanced by the circumstance that from the 12 th century all education was in the hands of the Church. Tuition was conducted in the supranational language - Latin. Its mastery took the most of the time: one had to learn writing and reading in it, also to convey thoughts in several styles, according to the rules of rhetoric. The essentials of high and higher education consisted of philosophy (even in the 16th century Aristotelianism was still dominant), which covered natural and exact sciences. In addition, senior students also took courses in theology, law and medicine.

Alongside the Latin school, some West European countries began to establish schools (in the 13 th century) using the national vernacular as the language of instruction (in England, Germany from the 13th century, in Italy, France, Holland from the 14th). This type of school with a slightly different curriculum was founded in cities, in some countries - at friaries. First of all the mother tongue was taught in elementary schools but soon some secondary schools were established in a number of states. The only type of school to be developed in Lithuania was Latin, sponsored by the Church.

The curriculum of the Latin school had been transferred to Lithuania almost unchanged - exept the language of interpretation was different - to Lithuanians, it was Lithuanian, if the teacher knew it. The University of Vilnius had faculties of Philosophy, Theology, from the mid-17th century also that of Law. In the late 18 th century a Faculty of Medicine was also established.

In Lithuania all the aforementioned methods of education the Baltic, formed by agrarian culture, and that of the Latin school, also the ecclesiastic method - existed side by side.

In the first quarter of the 16 th century the situation in Lithuania was such that the demand for school education was greater than could be met by the Lithuanian schools and other ways of instruction. And the youth returning from Central and Western European 
countries had heard and seen the purposes and ways of reforming the old European universities, had seen and read professors' books discussing what the youth should be studying. They were familiar with the questions confronting philosophy. The majority of arguments on education rested on the truths established by the teachers and men of wisdom of Antiquity and the aim was to get wider knowledge of classical culture. In Europe the zealous epoch of the Renaissance was generating a new phenomenon - a public movement - the Reformation. In the Protestant countries it brought church activities closer to the grass roots, introduced the mother tongue into Church ceremonies and doctrine, and forced the Catholic Church to seek new ways of influencing society.

The active measures of the Lithuanian cultural community, experiments in the reconstruction of the public life in the 16th-18th centuries, and rivalry between the forces of the Reformation and Counter-Reformation created prerequisites necessary for the formation of a complete educational system in Lithuania: in 1539 at Vilnius the Lutheran Abraomas Kulvietis established the first college. This functioned for three years. The Latin Catholic College of Vilnius was founded in 1570; in 1579 it was raised to the rank of a university. The fact that the College was established by the Jesuits helped the Latin school to consolidate in Lithuania.

The mature intellectual level of the Lithuanian intelligentsia in the first half of the 16th century, and the quality of erudition provided by the European school, the beginning of Reformation, the historical accident that existing schools in Lithuania were unable to meet the demands of society, generated the first Lithuanian tracts - reflections on the state of Lithuanian culture, society and education. Hence, in the mid-16th century the first texts of Lithuanian pedagogical thought appeared. They arose out of the realisation of the need to change school education, reform and improve it, to adapt to the needs of the Lithuanian society and its perspectives.

Lithuanian pedagogical thought, as the ideas of public education and man's upbringing, projects, new attitudes, was expressed in the texts of different nature and genres: its fragments appeared in fiction, publicity (the treatise of Mykolas Lietuvis (Michalo Lituanus) De Moribus Tartarorum, Lituanorum et Moschorum (ca. 1550), the book by Andrius Volanas (Andreus Volanus) De libertate politica sive civili (1572), Abraomas Kulvietis (Abrahamus Culvensis) Confessio fidei (Confession of Faith, 1542), in the histories written by Maciej Stryjkowski and Albert Kojalowicz-Wijuk (Lith. VijūkasKojalavičius), in the prepared and published text-books, collections of sermons.

Although sermons had been preached in churches since the years of Lithuanian baptism, nothing can be said of their contents, as they have not been recorded. Frequently the priests would use for their sermons texts written in foreign countries, translate them and 
base their own sermons on them. The dogmas of such sermons showed what ideas or regulations spread in Lithuania had been borrowed from the neighbour states. They disclose what was considered valuable albeit not locally created. The educational value of the sermons, their pedagogical ideas can be subjected to analysis only from the times that left texts, especially printed ones.

The first original collection of sermons was written in Lithuania Minor by the Lutheran Jonas Bretkūnas (Johannes Bretke, 1536-1602). His Postilla, printed in 1591, started the development in Lithuania of the genre, reflecting the Lithuanian pedagogical thought. J.Bretkūnas' pedagogical and educational outlooks deserve a deeper investigation which has not yet been undertaken.

The first collection of sermons in Lithuania was translated into Lithuanian by Mikalojus Daukša (1527/1538-1613). His Postilla (1599) is of major importance to the development of the pedagogical thought in Lithuania, especially the preface written by him personally in which he promised "...to offer a chance to think over and consider more important things, to call to take more ardent care of the mother tongue and to spread it". An original collection of sermons was prepared in Lithuania by Konstantinas Sirvydas (Sirwyd) (1579-1631) whose Punktai sakymu (Gospel Points) were published in Vilnius in 1629,1644 . These original texts expressed a purposeful attitude of their authors to the Lithuanian culture, language, views on the foundations and goals of shaping a personality.

Another big group of texts reflecting the Lithuanian pedagogical thought consists of school text-books and dictionaries. Since the late 16th century also special pedagogical works and instructions were written in Lithuania; magnates, nobles or their hired professional educators wrote instructions as to how and in what matters their descendants ought to be trained. The authors set for their pedagogical positions in text-books, explained them in their prefaces. In the mid-17th century a professor of the University of Vilnius, A.A. Olizarovius (A.A. Olizarowski, 1610-1659), wrote an extensive study (1651) on contemporary social science which accumulated and conveyed the summary of the Western and Central European pedagogical thought of that period, independently represented by the author. The chapters of A.A. Olizarovius' book on education were of major value to the development of the Lithuanian pedagogical thought and cultural history, as they presented a considered experience of the European scholars, and clearly suggested the modernization of some traits of society's behaviour through education. He managed to link Western European pedagogical thought with the tasks facing the society in the Grand Duchy, made positive suggestions of innovations, capable of serving the state's culture. He encouraged the creation of state schools and presented a broad programme for the nobility's education that would be able to modernize the behaviour of this section of the society, help it to bend in the direction of techno- 
logical revolution together with the other West European societies which were entering a new stage of modern history.

Hence the professional pedagogical thought of Lithuania, i.e. reflections on what the education system should be like, how it should be improved, how to perfect its contents, methods, how to raise a man's personality, how to form values in a society, can be defined from the time it was first recorded, i.e. since the mid-16th century, when a deliberate effort to reform, change and adapt existing educational methods in Lithuania began. The professional pedagogical thought of Lithuania grew in the field of a professional, script-based culture. The power of its thinkers' intellect and cultural self-consciousness initiated a strong bias in the curriculum and methods of the Latin school and church education in Lithuania, and in effect began to adapt the educational phenomena of this cultural model to public needs, introduced a number of useful things into it, began to change the shape of this model. The propagation of Lithuanian pedagogical thought and its execution was undertaken by a great deal of the 16th17 th century intellectuals, yet not everyone's contribution into this labour has been an object of research (e.g. J. Bretkūnas'). A. Kulvietis, Mykolas Lietuvis, Mikalojus Daukša, Konstantinas Sirvydas, Adamus Rassius, Žygimantas Liauksminas, Aaron Olizarovius, Albert WijukKojałowicz made such contributions which, taken together, composed one stage of the Lithuanian pedagogical thought.

The early 16th century marked the beginning of an intensive search to learn and evaluate the pedagogical theories of Western and Central Europe, its school system, of deliberate attempts to improve the adopted West European system of education to the needs of Lithuanian culture, which were productive. The works produced by the most outstanding personalities of the 16 th - first half of the 17 th centuries A. Kulvietis, S. Rapolionis, M. Mažvydas, Mykolas Lietuvis, M. Stryjkowski, M. Daukša, K. Sirvydas, A. Rassius, Z. Liauksminas, A.A. Olizarovius, A. Wijuk-Kojałowicz, D. Kleinas, the power of their intellect and mind, their perception and their proposals, the statement of moral regulations to society were landmarks in Lithuanian culture. They grew from Lithuania, mostly from the Lithuanian-inherited standard and the needs of the Lithuanian nation. Their individual activities and thoughts were part of the cultural process occurring in Lithuania and in GDL as a whole. On the other hand, each of them was making individual efforts to create the cultural values of Lithuania. Over those centuries the above mentioned intellectuals both by their activities and theorizing sought ways to include their subjects into the successive system of education, types of schools, curriculum, to adapt from the familiar West European theories the points that they considered valuable and practicable in Lithuania. During these centuries attempts became obvious not to transfer mechanically onto the soil of Lithuanian cultural life foreign educational institutions, and ideas, but to adapt them creatively and to form such an 
option as would be conducive to the progress of Lithuanian society. Our intellectuals, however, were not always able to accomplish this. A great deal of the phenomena would first be transferred to Lithuania mechanically, with comparatively very few changes. For instance, the Jesuit school system, the structure of colleges and the curriculum were regulated by the uniform teaching regulations of the "Ratio studiorum".

However, the entirety of a specific Lithuanian educational variant (either at the level of real institutions or that of theoretical thought), which in the cultural sense would match the needs of the Lithuanian nation, guarantee its existence, was not created in Lithuania. Yet the foundations were laid: 1) good acquaintance was made with some of West-European pedagogical theories which were reconsidered and frequently assessed; 2) different attitudes were adopted; 3) concrete projects were suggested for the adaptation of education in Lithuania to public need; 4) the role of language in the education system was understood; 5) elements of Lithuania's own culture were introduced into the contents of the Latin secondary and higher education, transmitted from Western Europe.

During the 16th-17th centuries writers on the Lithuanian pedagogical theory created the fundamentals of new perspective entities for the Lithuanian culture which under proper political and social circumstances could be matured, and attempts made to bring them into effect. However, during the hundred years following the mid-17th century, Lithuanian intellectuals were unable to develop this creatively initiated accommodation of the West-European educational model to the needs of the Lithuanian culture in the territory of the Grand Duchy. The flow of cultural creation, which had been started, was destroyed by political and social circumstances. During the latter half of the 17 th - the 18 th centuries new, fruitful regulations and ideas for the existence of the Lithuanian nation were more efficiently developed by the cultural community of Lithuania Minor. Matthew Prätorius and Kristijonas Donelaitis were born there.

What did Lithuanian pedagogical thought achieve between the 15 th and the first half of the 17 th centuries? How far did Baltic culture advance in mastering and adjusting to its needs one of the spheres of a different cultural model - education? Of the cultural type based on script, specialization, professional creation, with special cultural institutions.

The first Lithuanian Protestants, A. Kulvietis (ca. 15101545), S. Rapolionis (ca. 1500-1545), M. Mažvydas (before 1520 1563), devoted their lives to the assimilation of Western Europe's scientific knowledge in secondary and higher education, to familiarity with the curriculum and system of the Latin School and the perception of the European innovations which accompanied the Reformation. By their abilities, cultural activity and openness to innovation in the area of intellectual work they equalled the brightest personalities of that 
time: the Prussian Duke Albrecht waited until S. Rapolionis and A. Kulvietis were awarded degrees, and endowed S. Rapolionis with the highest post of the University of Königsberg - the chair of divinity. These first prophets of the Reformation in Lithuania had a good sense of the demands of the Lithuanian nation and saw the disadvantages of the existing system of education. Each of them made every effort to improve the situation. A. Kulvietis, who founded the first secondary school in Lithuania (it functioned in 1539-42), believed that the wealth of the Church ought to be used for the support of poor pupils.

Throughout the 16th century Lithuanian intellectuals tried to ascertain the place of language in culture and school. In this respect two directions were obvious. The first began to consider the place of the native tongue in culture (M. Mažvydas, M. Daukša). Nevertheless, the majority of the Lithuanian 16th-17th century intellectuals, even M. Daukša, did not produce texts that could serve as declarations of their cultural self-consciousness. The latter can be defined from the results of their work as well as from what they considered essential values. One has to answer the question what sum total of motives had matured the determination to prepare the Lithuanian book, how he appraised the state of Lithuanian culture at that time, whether he predicted any perspectives for the development of Lithuanian culture - all these questions are part of the definition of cultural self-consciousness.

M. Mažvydas wrote that one of the major values of human life is faith. In this he observed the doctrine of the Lutheran Church. "Faith showing the true way to salvation alone expiates a man from the law's damnation, from God's wrath, from condemnation to eternal death". A man has to prove his faith by the fruits of his activity. Thus eternal life after death is the most important incentive and value of human life. The second fundamental idea forming his principles is the equality of religious people against God. He wrote: "Eternal life is a blessing common to all", and this was the chief reason to demand that rituals were equally understandable to everyone. Holy Writ is available to everybody, translated into the mother tongue - Lithuanian, not only read in Latin by the clergymen. The wish to create for the religious people equal opportunities seeking salvation encouraged the Lithuanian Protestants to take up action and to assess the state of Lithuanians. The perception of the native Lithuanian language was to M. Mažvydas an utterly conscious cultural commitment.

The Protestant M. Mažvydas prepared the first books in the Lithuanian language. The first Lithuanian book Katechismusa prasti žadei (Catechism) was published in Königsberg in 1547. His book could help expand the use of the Lithuanian tongue in the public life church, elementary school. Mažvydas made the first step towards the possibility of spreading literacy on the basis of the native language Lithuanian, of the people in all walks of life becoming literate; he pro- 
posed to teach Lithuanian at the parochial (elementary) school and to establish this kind of school at home - on the farms of Lithuanian peasants. At the same time Mažvydas tried to implant script-based cultural subjects into the Lithuanian-language agrarian culture, and to insert the native Lithuanian tongue into Latin education.

Mažvydas who had prepared a book in Lithuanian and published it in Königsberg devoted it to the whole Lithuanian nation where it dwelt at that time: both in Lithuania Major and Minor. In the dedication to Catechism he refers to the Grand Duchy of Lithuania as the "blessed homeland of great rulers, glorious Lithuania". In another dedication - to Giesmynas (Hymnal) he wrote: "To renowned Lithuania, the happy nurse of great leaders". "To you, honourable pastors and teachers, we present this Catechism, unpolished and brief and also in our Lithuanian tongue, so that the service of word survives and is transferred to future generations", was written in the Catechism's Latin preface "To the Pastors of Lithuanian Churches". This is the first principle to be so explicitly recorded and published in our cultural meditations: the Lithuanian nation is where the speakers of Lithuanian live.

The principles of Mažvydas' cultural self-consciousness, the perception of the needs of native culture and the significance of the mother tongue, his own high erudition and openness to the experience of other countries, their newly emerging phenomena were the major reasons that served Mažvydas' becoming the creator of a new occurrence in his native Lithuanian culture. However, it seemed to Mažvydas that the other areas of Baltic culture: the Lithuanian countryside's traditional way of passing the experience, customs, folklore, ceremonies connected with work and other essential realia of human life, a specific world-vision and world perception are incompatible with the script-based intellectual culture, with his ideal of an educated and literate society. He referred to the agrarian culture as heathenish, acclaimed this cultural model only from the point of view of pure Protestant faith and did not see any possibilities in the future to unite the values created by both cultures.

In this respect M. Daukša, a Catholic, had a wider perspective of the bonds essential for the nation's existence that were inherent in the Lithuanian agrarian culture: customs, the inhabited land (territory), language. He explained clearly and persuasively that people are gathered into a nation by language as well as by common traditions and dwelling place. Therefore, he wrote that the nation with its culture was as self-contained as any other nation, and its language the closest tie that ought to be legalized in the state. Hence the preface to Daukša's Postilla formed a universal principle - to develop national ties. However, he did not specify his view on education. Daukša declared the tie created by a language to be the foundation of the state. It was a vitally important innovation, a superb extension of the principle initiated by Mažvydas. Already much later this principle of 
Daukša was remembered and further developed by 19 th century Lithuanian intellectuals - creators of the written language and culture.

The second trend gave priority to the Latin language. Michalo Lituanus and A.Rotundus believed that the similarity of the Lithuanian language to Latin (their kinship was exaggerated, thinking that the Lithuanian language was substandard Latin) allowed them to consider the Latin language and the Latin-based school one of their own. Following this way of thinking, there did not seem to be any need to try and impart the Lithuanian language with any weight in the state or at school, to create any special Lithuanian institutions. Michalo Lituanus suggested that the Latin language, as the language of Lithuanian ancestors (he supported the theory that Lithuanians originated from Italy) be declared the state language, used universally. The consolidation of the positions of Latin in Lithuania had a number of advantages: 1) it was neutral with respect to any national language; 2 ) it did not give preference to any national vernacular; 3) it excluded mediators in getting familiar with the West European classical, medieval and Renaissance culture as well as with that of the developing New Ages.

Apart from this, the position of the Latin language in Lithuania was strengthened by the spread of Renaissance ideas. In Western Europe Renaissance figures had a double view on the languages to be used in cultural activities: some of them tended to use their mother tongue (Dante wrote his poems in Italian), others, basing on the authority of classical culture, rigidified the use of classical Latin. In Lithuania, the Latin trend took the upper hand. The establishment of the Latin language in the Lithuanian school system was enhanced by the fact that the privilege of founding a university was granted to the Jesuits - advocates of the Latin school. During the 17th century the network of their colleges expanded and the number of Latin school graduates increased. Late in the 17 th century the majority of secondary schools were maintained by the Jesuits. In addition, the followers of Protestantism in Lithuania were also basically the advocates of the Latin school. Since the early 16 th century both Protestants and Catholics placed the native language in the elementary school, but the language of instruction, really depended on the teacher or clergyman who was in charge of maintaining the school. In the parochial (elementary) schools the language of instruction could be Latin, Lithuanian or Polish.

Both regulations concerning the use of languages in the Lithuanian culture and education of the second half of the 16th century were argued theoretically and existed side by side, yet gradually the position of Latin strengthened. Alongside these two tendencies, a third one existed in the real life of the noble society. The Chancellor of the Grand Duchy of Lithuania, Leo Sapieha, made a suggestion late in the 16th century to grant the status of the state language to the chancery language of GDL's eastern Slavs - the written language of 
legal documentation and the Lithuanian Statutes. Political life within the federal Polish-Lithuanian state from 1569 encouraged the use of a supranational language - spoken Polish.

In view of all these circumstances, the tendency most advantageous to the Lithuanian culture - Mažvydas' and Daukša's realization of the need to use Lithuanian at school and in state life - in the 16 th -17 th centuries did not develop into the objective to create secondary schools in the Lithuanian language and to supplement their curriculum with the subjects of Lithuanian culture.

In Western Europe, schools of a new type were mainly founded in the cities. The urban schools would be the first to reach to the new needs of the society to change the syllabus, to begin the instruction in the mother tongue and spoken foreign languages. Yet since the beginning of the 17 th century, the development of the Lithuanian economy and the political situation were not conducive to the growth of the cities, or to the increase of their financial might, so these did not become the founders of a new type of schools. The social and political conditions of the nation's life in Lithuania were not favourable to the development of a peculiar variant of the educational model, based on the native language and the syllabus containing the disciplines of Lithuanian culture. During the 17 th century this idea of the native language-based education, initiated by Mažvydas and Daukša, was more favoured in Lithuania Minor. In the 17th century the trend was continued in Tilsit by the Lutheran Danielius Kleinas (Daniel Klein, 1609-1666) and his colleagues.

Danielius Kleinas strove for the teaching of Lithuanian at the particular school in Tilsit during the 17th century and managed to attain this goal. To this end Danielius Kleinas wrote a grammar of the Lithuanian language Gramatica Litvanica (published in Königsberg in 1653).

The Lithuanian cultural community was largely concerned with the accommodation of the secondary school curriculum to local needs. A number of innovations were suggested in this area; some by the Protestants, other by Catholics.

The Lithuanian Protestant educator Adomas Rasijus (Lat. Adamus Rassius, ca. 1575-1627/28) suggested that the system of establishing schools in Lithuania be diversified by new ones - specialized academic type grammar schools using the Latin language. The foundation of this type of school was already ripe in the whole Europe: several decades past the death of A.Rassius - in the second half of the 17 th century the establishment of similar schools was undertaken there (knightly academies and grammar school). Thus, at the level of theoretical thought A.Rassius proposed to the Lithuanian education an innovation which was just originating in Europe and had real perspectives there. In Lithuania, however, because of the character of its political life, the mid-17th century wars, which were so difficult and illfated to Lithuania, this innovation was never put into action. 
The personalities reared in the environment of the University of Vilnius did not raise the questions of the improvement of the education system, did not develop the principles of Mažvydas and Daukša regarding the place of the native language in education. They tried to combine the needs of the Lithuanian culture with the curriculum of the Latin Jesuit school in a different way: seeking to bring innovations into the syllabus without any essential changes or efforts to discuss the matters of the school system.

In order to match the curriculum of secondary and higher education with the demands of Lithuanian culture, the former had to be thoroughly examined. This was performed by the first generation of teachers trained at the University of Vilnius. The best professors of the University had mastered the scope of tuition subjects and the method of their instruction at the European Jesuit colleges and universities. Over the first half of the 17th century the professorship of the University of Vilnius had written and presented some original textbooks of universally delivered courses, meeting the standards of analogous universities in Europe: Ž. Liauksminas (1596/7 - 1670) from Žemaitija wrote in Latin a textbook in the essentials of rhetoric and logic, widely used abroad, and some textbooks of musical theory; the Masurian-born poet Matthew Sarbievius (Sarbiewski, 1595-1640), closely related with the life of GDL, wrote on poetic theory; Martin Smiglecki (Smiglecius), born in Lvov, - on logic; Aaron Alexander Olizarovius (Olizarowski) completed the formation of a course in public theory. So 30 years after the university's foundation, courses in humanities were fully assimilated, new methods of their delivery were commenced. This is how the appropriation of the pan-European culture's university curriculum took place; the mode of reasoning, the scope of knowledge, the methods of conveyance became a property of the intellectual society in Lithuania.

On the other hand, attempts were made to supplement, although moderately, this European curriculum. One of the major steps in this direction was made by Konstantinas Sirvydas (Syrwid). He prepared a trilingual (Polish-Lithuanian-Latin) dictionary. First of all this book established the Lithuanian language as auxiliary to those studying in Latin and was a support to the members of the Lithuanian academic circle at Vilnius University. On the other hand, he fostered that layer of the Lithuanian language which was necessary for the science, intellectual language, for the description of life in other countries, the expression of abstract notions. The work accomplished by K.Sirvydas was used for several centuries by the Lithuanian intellectuals, his dictionary served even for the activists of the 19th-century Lithuanian rebirth.

The efforts to include another Lithuanian cultural sphere the study of its past - into the curriculum of high education belong to Albert Wijuk-Kojalowicz, professor of Vilnius University. As long as the teaching of Lithuanian history was not included in the Jesuit "Ra- 
tio Studiorum", he invented a way how to present Lithuanian history to pupils and students: he wrote Lithuanian history in the form of a Latin reader. Studying Latin, the youth could also study the history of their nation and state. This novelty drew together two cultural phenomena - the need, adopted from the European system of education and perceived by the Lithuanian nation to get to know and write its own history.

The joint efforts of the cultural communities of the part of GDL and Lithuania Minor resulted during the first half of the 17th century in laying the foundations for the science of the Lithuanian language: the old bibliographers mention that K.Sirvydas had written Lietuviu kalbos raktas (A Key to Lithuanian) (unfortunately, not extant), the first extant grammar is D.Kleinas' grammar published in 1653. The birth of Lithuanian philology showed the ongoing interaction between the intellectual European culture and that formed in the Lithuanian language.

The publicistic, belles-lettres and historical literature created in the 16th-17th centuries, the collections of original sermons or their summaries provide enough ground already to look at the time's human world-outlook and world-perception, to understand what ideal of a personality was set by those who were able to seek it. What new principles of man's behaviour were considered worth forming by our intellectuals.

Describing human world-outlook and world-perception in most general terms, it becomes clear that in the Lithuanian nation there were fairly sharp distinctions between those prevailing in the agrarian community and among intellectuals, magnates, nobles. These properties have been scarcely studied by our scholars. No doubt, in the agrarian community the prevalent philosophy of life was that inherited from the old Lithuanian culture which, however, was changing gradually and got adjusted to the living conditions of the 16th-17th centuries. The world-perception of this part of the nation retained a deep understanding of a close proximity of land and nature, a cyclically understood time. The conception of the Catholic or Protestant faith in God was already present. The faith that dominated in the Lithuanian agrarian community could be called a variety of popular Christianity, quite remote from the Christian philosophy of life formed at that time by Europe's Christian theologians. Mažvydas' attitude to the faith of his parishioners exposed the presence of a big difference between the Christianity offered by educated theologists and that existing in the peasant environment. The period's popular Christian world-view ought to be called syncretism, i.e. a blend of Christianity and the old Baltic faith. The Christian world-view of the educated Lithuanian cultural community was akin to European of the same stratum.

As is obvious from the writings of Mykolas Lietuvis, A. Rotundas, M. Stryjkowski, M. Daukša, the 16th century intellectuals, 
educated people, the student youth, i.e. the culturally minded public sector, exhibited the basic traits of human world-perception in the great cultural epoch - Renaissance. It declared a personality's independence and responsibility for the self-developed virtues. To the cultural community of the Lithuanian Renaissance the key virtues were patriotism, activity, education, wisdom, smartness, ability to perform illustrious acts, to create their motherland by work, to know their past and to perpetuate themselves in history. A model citizen of the state is one who feels the ties of his nation, having state and national selfconsciousness, able to perceive coexistence with other nations.

At the margin of the 16th-17th centuries this Renaissance perception of a man's place in society and world began to change: gradually it submitted its positions to another cultural epoch - Baroque.

The world-perception of the Baroque man was spread widely in Lithuania by clergymen through sermons, hymns, at the colleges and University - through lectures and performances. These traits of pan-European cultural world-perception reached the world-perception of much wider sections in Lithuania in comparison with the cultural epochs preceding Baroque - Gothic, Renaissance. Baroque penetrated deeper into the layers of agrarian world-outlook. However, we do not yet know, what and in what form the Lithuanian peasants adopted from the 17th-century preachers, schools, pilgrim missionaries. K.Sirvydas' sermons, A. Wijuk-Kojalowicz's Lithuanian history and his other writings moulded the world-perception of a man, relying on God's mercy and will, faithful to him, realizing his humbleness in reality, yet hopeful that through spiritual efforts he can improve by sorrow. There was a huge gulf in this world-perception between the man's realization of his meanness and a possible spiritual dignity. This distance between two antipodes upheld a man in spiritual suspension, forced him to concentrate on inward problems. During the Baroque epoch a principle was formed that a personality's most valuable properties were trust in God and faithfulness to God and Motherland, striving for spiritual perfection, suffering through the difficulties of reality, submission to them. The priority of morals in state activities was considered by A. Wijuk-Kojalowicz indispensable to every politician, no matter what concretely it could entail for the historical situation of the state. Moral values were declared to be the apex of all values. Somewhat different ideals of a personality were stated by the Lithuanian secular intellectuals of the first half of the 17th century: Protestant Rassius and Catholic Olizarovius. They were oriented not to the demands of internal spiritual life, not to a man concentrated on his sorrow, but to the properties of a man trying to affect social reality. Both thinkers called to raise a personality able to reform public life. In this respect the formation of a new attitude to work was a major asset.

Rassius initiated the formation in Lithuania of such personal standards and attitudes to work that would raise the value of the third 
estate of realm - burghers, would allow the modernization of the noblemen's attitude to trade. Olizarovius tried to change the views on manual work, i.e. on crafts and trades. His motivation was, that ability to engage in crafts would help to make a decent living for the impoverished section of the nobility, and this work should not diminish the nobility's dignity. The statement of such principles in Lithuania could become the society's preparation for the approaching technical revolution in Europe (at that time it was beginning in England). These outlooks of Rassius and Olizarovius were innovations in the pedagogical thought of Lithuania. However, these issues, well understood by both Rassius and Olizarovius and offered to the Lithuanian society for consideration, were never brought into practice. The nobility continued to trade in manor products, but blocked the roads to crafts and trades, and the articles of the Lithuanian Statute dealing with the deprivation of noble status, stipulated the prohibitions for the gentry to engage in trades.

In the writings of Rassius and Olizarovius an individual's value consisted in education, self-rearing, the development of innate gifts and talents, aims to be useful to the society, action, ability to undertake "lofty and heavy tasks". Thus the several aims of individual's education existing in Lithuania tallied with the public life of the 17th century Baroque epoch.

The creative work of the Lithuanian cultural community of the 16th-17th centuries, the views they represented showed that the brightest part of the Lithuanian society was able to adopt a great deal of things from European culture, particularly from the sphere discussed - education. During that time it began a creative application of the assimilated forms and methods, trying to link them organically with the possibilities of old Lithuanian culture and subsequent evolution. This showed the efforts of the Lithuanian personalities to recreate the acquired cultural values, to apply and introduce into the existing system of Lithuanian culture. No matter that in the 16th-17th centuries some of the needs of native Lithuanian culture were clearly perceived, during those centuries there was not any organic combination between the needs of intellectual culture and the old agrarian culture. This process in Lithuania was for long interrupted by the mid17th century wars of the Polish-Lithuanian state with Sweden and Russia, which ruined the state economy, destroyed nearly half of the population. In addition, the character of the state's domestic life was unconducive to the fruitful continuation of this trend and pedagogical thought and the initiated process begun in the GDL part of Lithuania, remained static for nearly the entire one hundred years till the middle of the 18th century.

The intellectual and creative powers of the above-discussed figures resulted in the 16th-17th centuries in several tendencies of the appropriation of innovations. The work they accomplished was the beginning of the process, so necessary to the culture of every nation, 
and the basis for its creative development in the future. However, over the 16th-17th centuries our intellectuals were still unable to endow at least one educational sphere with its final shape. The unilateralism of the school system arising from social and political conditions, the ever growing use of the Polish language in writing and for supranational functions during the 17 th century, the beginning of the state's political decline overwhelmed those rudiments. A fairly considerable part of the gentry was assimilating some of the principles, forms of behaviour, moral orientations from neighbouring Poland, without any effort to re-create them, or adapt them to their native cultural system. They did not realize the consequences of all this.

Passive transmission was one of the factors encouraging an ever wider use of Polish for writing and as a public language. Life in a federal state with Poland where the gentry had already won itself certain privileges, the selected standpoint - the supremacy of a privileged individual's (nobleman's) interests over those of the state, society, stimulated the conservative attitudes. "Nihil novi" (nothing new) satisfied the majority of the ruling estate, after their privileges had been recognised. This blocked the opportunities for society's rapid modernization. The latter was going on in most European states.

The factors of social, economic and political life, the principles supported by the majority of the noble society managed to overpower all that had been realised and presented to their society by the Lithuanian intellectuals of the 16th-17th centuries. They prevented putting into effect the results of the pedagogical thought and thereby failed to improve the condition of the entire culture of the Lithuanian nation and the existence of the state proper, to involve its intellectual spheres in the system of native ethnical culture. Over the next, the 18 th century this work was continued, with more results than by GDL intellectuals, by the cultural workers of Lithuania Minor. 